\title{
A need for better housing to further reduce indoor malaria transmission in areas with high bed net coverage
}

\author{
Dickson W Lwetoijera ${ }^{1,2^{*}}$, Samson S Kiware ${ }^{1,3}$, Zawadi D Mageni', Stefan Dongus ${ }^{1,2}$, Caroline Harris ${ }^{1,2}$, \\ Gregor J Devine ${ }^{4}$ and Silas Majambere ${ }^{1,2}$
}

\begin{abstract}
Background: The suppression of indoor malaria transmission requires additional interventions that complement the use of insecticide treated nets (ITNs) and indoor residual spraying (IRS). Previous studies have examined the impact of house structure on malaria transmission in areas of low transmission. This study was conducted in a high transmission setting and presents further evidence about the association between specific house characteristics and the abundance of endophilic malaria vectors.
\end{abstract}

Methods: Mosquitoes were sampled using CDC light traps from 72 randomly selected houses in two villages on a monthly basis from 2008 to 2011 in rural Southern Tanzania. Generalized linear models using Poisson distributions were used to analyze the association of house characteristics (eave gaps, wall types, roof types, number of windows, rooms and doors, window screens, house size), number of occupants and ITN usage with mean catches of malaria vectors (An.gambiae s.l. and An. funestus).

Results: A total of 36490 female An. gambiae s.l. were collected in Namwawala village and 21266 in Idete village. As for An. funestus females, 2268 were collected in Namwawala and 3398 in Idete. Individually, each house factor had a statistically significant impact $(p<0.05)$ on the mean catches for An. gambiae s.l. but not An. funestus. A multivariate analysis indicated that the combined absence or presence of eaves, treated or untreated bed-nets, the number of house occupants, house size, netting over windows, and roof type were significantly related $(p<0.05)$ to An. gambiae s.l. and An. funestus house entry in both villages.

Conclusions: Despite significant reductions in vector density and malaria transmission caused by high coverage of ITNs, high numbers of host-seeking malaria vectors are still found indoors due to house designs that favour mosquito entry. In addition to ITNs and IRS, significant efforts should focus on improving house design to prevent mosquito entry and eliminate indoor malaria transmission.

Keywords: House risk factors, Anopheles gambiae s.l., Anopheles funestus, ITNs, Malaria

\section{Background}

The Anopheles gambiae and Anopheles funestus complexes comprise the major and most efficient malaria vectors in sub-Saharan Africa [1]. Their transmission efficiency is mediated by their behavioural adaptation to feed indoors on humans [2]. To date, insecticide treated

\footnotetext{
* Correspondence: dwilson@ihi.or.tz

${ }^{1}$ Biomedical and Environmental Thematic Group, Ifakara Health Institute, P.O. Box 53, Ifakara, Tanzania

${ }^{2}$ Vector Biology Department, Liverpool School of Tropical Medicine,

Pembroke Place, Liverpool L3 5QA, UK

Full list of author information is available at the end of the article
}

nets (ITNs) and indoor residual spraying (IRS) are the mainstay for controlling malaria vectors and associated malaria transmission $[3,4]$. Despite the huge success of these interventions, residual malaria transmission cannot be addressed by ITNs and IRS alone, even at very high coverage $[5,6]$. Moreover, their sustainability is threatened by a widespread increase in insecticide resistance in the target species $[7,8]$. In Senegal, the initial successes of an ITN distribution program were partially confounded by an increase in insecticide resistance and a consequent rebound in malaria incidence [9] and in

\section{Biomed Central}


northern Tanzania the predominant vector $A n$. arabiensis has been reported to display avoidance behaviour against ITNs [10]. The integration of existing interventions with environmental management and socio-economic development through house improvement and screening offers a non-insecticidal, complementary approach to increasing protection against mosquito bites $[11,12]$. These additional interventions could enhance the interruption of malaria transmission through the reduction and prevention of human-vector contacts inside human dwellings. It has long been established that the transmission of many vectorborne diseases is facilitated by house designs that favour mosquito entry [13-15] and that housing improvements and screening have made substantial contributions to the control and elimination of malaria vectors in many richer countries [16]. Therefore, understanding house risk factors that are associated with reduction of indoor mosquito bites and disease transmission in different settings is crucial for disease vector control and elimination.

Several studies have identified and documented various house characteristics associated with mosquito entry. Presence of eave gaps, lack of a ceiling and lack of screening over windows and doors proved to be the major contributors to mosquito entry [16-20]. Furthermore, it has been shown in a randomised control trial that blocking all potential house entry points for mosquitoes substantially reduces vector densities and entomological inoculation rates (EIR) [19]. Other than protection against malaria mosquitoes, the use of screened houses offers protection against nuisance bites and other mosquito borne diseases $[15,21]$.

While this strategy is deemed efficient in reducing indoor biting and disease morbidity in low malaria transmission settings [16], its impact is yet to be examined in areas experiencing moderate to high malaria transmission and with high ITN coverage such as the Kilombero valley in south-eastern Tanzania.

A recent study in Northern Tanzania has shown a strong association between houses, individual and behavioural risk factors and malaria transmission [22]. However, the authors argued that it was important to complement these findings with entomological data in order to have a fuller understanding of malaria transmission inside human dwellings [22]. This study therefore assessed the impact of house characteristics on indoor vector abundance in communities with a high coverage of ITNs.

\section{Methods}

\section{Study site}

The study was carried out in Namwawala and Idete villages located in the flood plain of the Kilombero River $\left(8.1^{\circ} \mathrm{S}\right.$ and $\left.36.6^{\circ} \mathrm{E}\right)$ in south-eastern Tanzania (Figure 1). The epidemiology of malaria transmission and associated disease vector species composition within these villages has been well studied and documented over the past years $[23,24]$. Both villages experience an annual rainy season (Dec - May) and the main crops are rice

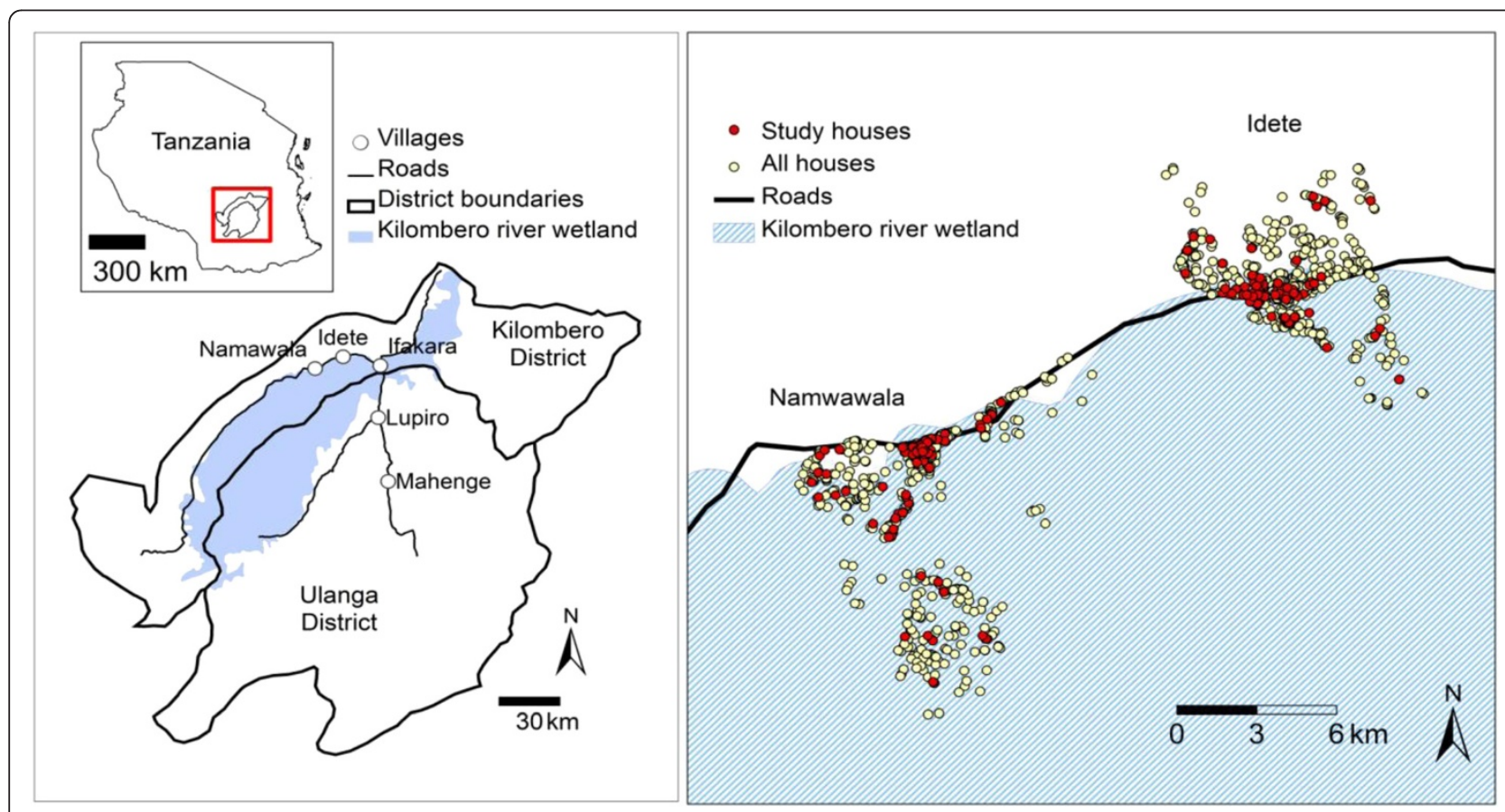

Figure 1 Kilombero and Ulanga districts $\left(8.1^{\circ} \mathrm{S}\right.$ and $\left.36.6^{\circ} \mathrm{E}\right)$ in Tanzania showing Namwawala and Idete villages (left) and spatial distribution of sentinel houses used for mosquito sampling (right) [25]. 
and maize. However, both villages have a relatively similar number of houses (Namwawala $=804$ and Idete $=844$ ), Namwawala has a high number of households (3909) compared to Idete (2932). Houses in Idete are built on relatively elevated areas compared to Namwawala. Approximately $92 \%$ of community members sleep under a treated net [23].

\section{Study design}

This longitudinal study was conducted over four years. A total of 72 houses from each village were randomly selected from Ifakara Health Institute (IHI) Demographic Surveillance System household list [26]. All selected houses were geo-located using a handheld GPS (eTrex, Vista, Garmin, USA). Each of the 72 houses was sampled monthly (i.e. 6 houses per day, 4 days per week and 3 weeks per month). This longitudinal study was carried out between January 2008 and December 2011, during which mosquitoes were sampled every month during 2008 and 2011, for 6 months of the wet/rain season (January to June) in 2009 and for 6 months of the dry season (July to December) in 2010. This totals 36 months of sampling.

\section{House risk factors}

Structured questionnaires were used to record ownership, number and status of bed nets (either treated or untreated) including the one LLIN provided by the research team in this study, and the number of house occupants. The house characteristics which were recorded include house size, number of sleeping rooms, presence and size of eave gaps, number of windows, presence of window screening, number of doors, presence of ceiling, wall and roof types. These factors were correlated with mosquito densities indoors (an indicator of human biting rate) over time in both villages, at house level and were monitored yearly to accommodate any significant changes. Representative house types, which are commonly found in the study area are shown in Figure 2.

\section{Mosquito sampling and processing}

Mosquitoes were sampled using miniature Centre for Disease Control (CDC) light traps (model 512, USA). One CDC light trap was set per house, placed 1-1.5 m above the ground close to the foot of a bed with an occupant sleeping under a treated net, and left to run for 12 hours (7 pm-7 am). For every participating house, one LLIN (Olyset, A to Z Textiles Mills, Arusha, Tanzania) was provided to protect the bed occupant where the CDC trap was set. Each morning of a sampling night, mosquitoes were collected and killed using chloroform and were morphologically identified in the field. Furthermore, female mosquitoes were classified as being unfed, partially fed, fully fed or gravid [2]. Subsamples of five mosquitoes from each trap were individually stored inside a tube containing cotton wad and silica gel beneath. Polymerase chain reaction (PCR) was used for identification of Anopheles gambiae [27] and An. funestus Giles [28] complexes, whereas an enzymelinked immunosorbent assay (ELISA) was used to determine sporozoite infection in malaria vectors [29]. Unprocessed mosquito samples were stored on silica gel at room temperature.

\section{Ethics}

The study approval was granted by the Ifakara Health Institute Institutional Review Board (IHRDC/IRB/No. A-32) and the National Institute of Medical Research (NIMR/HQ/R.8a/Vol. IX/764). The benefits and possible risks associated with the study were explained to the house occupants before commencement. After consenting, the head of the house was asked to sign two copies of the informed consent forms, of which, one remained with the head of the house and the other copy was kept by the study investigator.

\section{Data analysis}

The analysis was performed using generalized linear models (GLM) (MATLAB R2012a, Poisson distribution, 95\% confidence interval) to assess the impact of each

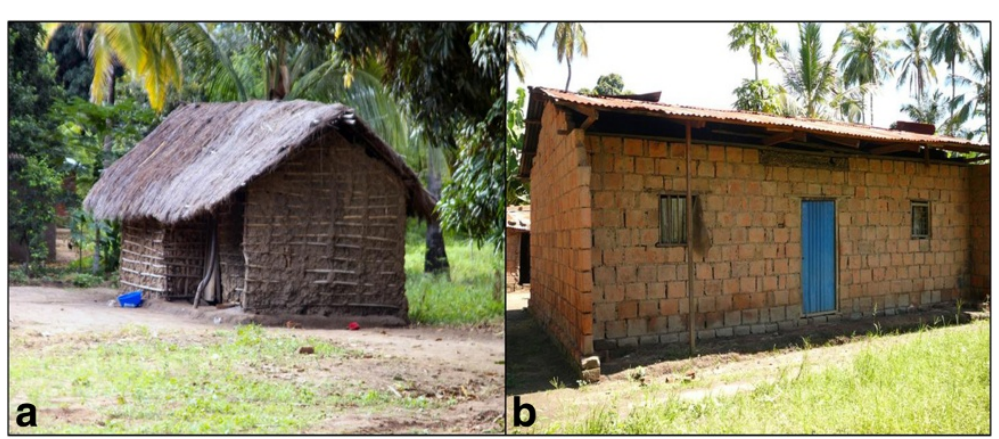

Figure 2 Representative house types commonly available in Idete and Namwawala villages. A temporary house (a) and a permanent house (b). 
individual house factor on the mean catches of $A n$. gambiae s.l. and An. funestus for both villages. Model estimate (ME) value was generated for each factor in comparison to a reference category. If the sum of ME for a factor and reference category was more than that of $\mathrm{ME}$ for a reference category then a factor increases indoor mean catches of mosquitoes, otherwise it decreases. Thus, ME value for a factor indicates by how much a factor increases or decreases the indoor mean catches when compared to a reference category. We categorized the house factors as follows: Eave gap: present or absent, eave gap size (small: $<9 \mathrm{~cm}$, medium: $9-15 \mathrm{~cm}$, large >

Table 1 Parameters associated with Anopheles gambiae s.l. density in Idete and Namwawala villages

\begin{tabular}{|c|c|c|c|c|c|c|}
\hline \multirow{2}{*}{$\begin{array}{l}\text { An.gambiae } \\
\text { Factor }\end{array}$} & \multicolumn{3}{|c|}{ Idete $(\mathrm{N}=70)$} & \multicolumn{3}{|c|}{ Namwawala $(\mathrm{N}=72)$} \\
\hline & $\mathbf{N}$ & Estimate & $P$ value & Estimate & $\mathbf{N}$ & $P$ value \\
\hline \multicolumn{7}{|l|}{ Number Of Rooms } \\
\hline${ }^{\mathrm{a} O n e}$ & 37 & 2.31 & 0.0000 & 2.89 & 57 & 0.0000 \\
\hline More than One & 33 & -0.24 & 0.0035 & -0.76 & 15 & $<0.0001$ \\
\hline \multicolumn{7}{|l|}{ Number Of Doors } \\
\hline${ }^{\mathrm{a}}$ One & 30 & 2.45 & 0.0000 & 2.93 & 51 & 0.0000 \\
\hline More than One & 40 & -0.47 & $<0.0001$ & -0.64 & 21 & $<0.0001$ \\
\hline \multicolumn{7}{|l|}{ Number Of Windows } \\
\hline${ }^{\mathrm{a}}$ Up to 3 & 26 & 2.50 & 0.0000 & 2.85 & 53 & 0.0000 \\
\hline More than 3 & 44 & -0.51 & $<0.0001$ & -0.29 & 19 & $<0.0001$ \\
\hline \multicolumn{7}{|l|}{ Netting Over Window } \\
\hline${ }^{\mathrm{a}}$ Absent & 50 & 2.35 & 0.0000 & 2.85 & 60 & 0.0000 \\
\hline Present but damaged & 16 & -0.59 & 0.0004 & -1.65 & 9 & $<0.0001$ \\
\hline Intact & 4 & -085 & $<0.0001$ & -0.35 & 3 & 0.0005 \\
\hline \multicolumn{7}{|l|}{ House Status } \\
\hline${ }^{\mathrm{a}}$ Small & 12 & 2.76 & 0.0000 & 2.88 & 34 & 0.0000 \\
\hline Large & 58 & -0.71 & $<0.0001$ & -0.19 & 28 & 0.0008 \\
\hline \multicolumn{7}{|l|}{ Wall Type } \\
\hline${ }^{\mathrm{a}}$ Mud & 52 & 2.65 & 0.0000 & 2.88 & 32 & 0.0000 \\
\hline Cement & 18 & -0.66 & $<0.0001$ & -0.28 & 40 & $<0.0001$ \\
\hline \multicolumn{7}{|l|}{ Roof Type } \\
\hline${ }^{\mathrm{a}}$ Grass & 46 & 2.58 & 0.0000 & 2.94 & 19 & 0.0000 \\
\hline Metal & 24 & -0.65 & $<0.0001$ & -0.81 & 53 & $<0.0001$ \\
\hline \multicolumn{7}{|l|}{ Eave Status } \\
\hline${ }^{\mathrm{a} A b s e n t}$ & 46 & 1.50 & 0.0000 & 1.06 & 62 & 0.0000 \\
\hline Present & 24 & 0.94 & $<0.0001$ & 1.84 & 10 & $<0.0001$ \\
\hline \multicolumn{7}{|l|}{ Eave Size } \\
\hline${ }^{\text {a } S m a l l ~}$ & 26 & 1.80 & 0.0000 & 2.89 & 22 & 0.0000 \\
\hline Medium & 14 & 0.67 & $<0.0001$ & -0.05 & 27 & 0.4452 \\
\hline Large & 30 & 0.36 & 0.0028 & -6.24 & 23 & $<0.0001$ \\
\hline \multicolumn{7}{|l|}{ Number of Occupants } \\
\hline${ }^{\mathrm{a}}$ Up to 3 & 15 & 1.76 & 0.0000 & 2.35 & 34 & 0.0000 \\
\hline More than 3 & 55 & 0.54 & $<0.0001$ & 0.70 & 38 & $<0.0001$ \\
\hline \multicolumn{7}{|l|}{ Bed-net Status } \\
\hline${ }^{\mathrm{a}}$ Untreated & 47 & 2.33 & 0.0000 & 2.58 & 6 & 0.0000 \\
\hline Treated & 23 & -0.45 & $<0.0001$ & 0.22 & 66 & 0.0588 \\
\hline
\end{tabular}

a reference category, $\mathrm{N}=$ number of observations.

Note: Model estimate (ME) value for a factor indicates by how much a factor increases or decreases the indoor mean catches when compared to a reference category. 
$15 \mathrm{~cm}$ ), roof type: grass or metal roofs, wall type: mud or cement, number of occupants: up to three or more than three, windows: up to three or more than three, netting over window: intact, present but damaged or absent, doors: one or more than one, rooms: one or more than one, house size: small or large (small house considered to be the one with 1 room and/or 1 door and less than $37.4 \mathrm{~m}^{3}$ ), bed nets: treated or untreated. All houses had nets, and they were considered treated if the number of treated nets divided by the total number of nets in the house was greater than 0.5 , otherwise untreated.

\section{Results}

\section{Mosquito collections}

A total of 36490 female An. gambiae s.l., were collected in Namwawala village compared to 21266 from Idete village. Of these, approximately $98 \%$ were non-blood fed, $1.7 \%$ were blood fed and the remaining $0.3 \%$ were gravid. Namwawala had fewer female An. funestus 2268 than Idete village 3398. Although there were variations in catches, changes in vector abundance patterns between villages were similar over time. A PCR analysis of 6755 mosquitoes of the Anopheles gambiae complex yielded 607 (9\%) An.gambiae s.s. and 6148 (91\%) An. arabiensis mosquitoes. Furthermore, a sub-sample of 3025 An. funestus analyzed for species identification comprised 2805 (93\%) An. funestus s.s., 120 (4\%) An. rivulorum, and 100 (3\%) An. leesoni.

\section{House risk factors associated with An. gambiae s.l. indoor abundance}

Table 1 provides parameter estimates of each house risk characteristic when run individually in a univariate model and their significance on the mean catches for An. gambiae s.l. All factors in both villages had a statistically significant impact $(\mathrm{p}<0.05)$ on the indoor mosquito mean catches except bed net status in Namwawala $(\mathrm{p}>0.05)$. Houses where an eave gap was present had significantly higher An. gambiae s.l. mean catches (ME 0.94 in Idete and 1.84 in Namwawala) compared to when it was absent (ME 1.50 in Idete and 1.06 in Namwawala). Mosquito density increased with more people inside the house but decreased with large houses (more rooms, windows, and doors). Compared to a window with no netting, a house with a damaged net on the window had lower mean catches of An.gambiae s.l. and the catches decreased further for houses with an intact net. Furthermore, houses with either mud walls or grass/ thatch roofing had higher numbers of mosquitoes when compared to cement plastered walls and metal roofing.

The presence of bednets was significantly correlated to lower mean catches in Idete village $(\mathrm{p}<0.05)$. However, this was not the case in Namwawala village $(p>0.05)$. The ownership rate of nets in Namwawala village was
$89 \%$ for treated and $11 \%$ for untreated nets, whereas in Idete village it was $50 \%$ for treated and $50 \%$ for untreated nets.

\section{House risk factors associated with An. funestus indoor abundance}

The model estimates and $p$-values of each of the individual house risk characteristics, number of occupants and the bed-net status with their association with the mean catches for An. funestus for both villages are presented in Table 2. The presence of eave gap in the house was significantly correlated with increased mean catches of An. funestus (ME 1.42 in Idete, 2.48 in Namwawala, $\mathrm{p}<$ 0.05 ) compared to when eave gaps were absent (ME -0 .73 in Idete, -2.39). House size did not significantly affect mean catches in Namwawala $(p>0.05)$ but in Idete mean catches for An. funestus decreased with large houses (ME -0.60, p < 0.05), when compared to small houses (ME 0.85). Similarly, houses with more than one room or door had lower mean catches in both villages. Increase in number of windows did not significantly affect the An. funestus mean catches ( $\mathrm{p}>0.05$ ), however, the mean catches of $A n$. funestus significantly decreased with increased number of people in the houses in Idete $(\mathrm{p}<0.05)$ but not in Namwawala $(\mathrm{p}>0.05)$. Netting over windows did not reduce the mean catches in both villages. The mean catches of An. funestus were significantly lower $(\mathrm{p}<0.05)$ in the houses with cement plastered walls (ME -1.52 Idete, -0.55 Namwawala) compared to mud walls, as well as where metal roofs were present (ME -1.78 Idete, -0.89 Namwawala), compared to grass roofs. Mosquito catches decreased significantly $(\mathrm{p}<0.05)$ in the presence of treated bednets (ME -0.52 Idete, -1.03 Namwawala) when compared to the untreated bednet (ME 0.52 Idete, ME 0.85 Namwawala).

\section{Multivariate analysis}

A correlation matrix for all of the parameters was created to analyse the relationship among the house risk characteristics but no clear conclusion could be drawn. Thus, a multivariate analysis was performed using a 'stepwise regression approach' in which at each step the best variable (i.e. a house risk characteristic) with a significant level $(\mathrm{p}<0.05)$ is added. This analysis indicated that the presence of an eave gap, bednet status, number of occupants, house size and wall type had a significant impact on the mean catches of An.gambiae in both Namwawala and Idete. In Namwawala, also roof type and number of doors had a significant impact on the mean catches of An.gambiae.

Bednet status, number of occupants, house size, roof type and number of windows had a significant impact on the mean catches of An. funestus in Idete while netting over windows, presence of eave gap, bednet status, 
Table 2 Parameters associated with Anopheles funestus density in Idete and Namwawala villages

\begin{tabular}{|c|c|c|c|c|c|c|}
\hline \multirow{2}{*}{$\begin{array}{l}\text { An.funestus } \\
\text { Factor }\end{array}$} & \multicolumn{3}{|c|}{ Idete $(\mathrm{N}=70)$} & \multicolumn{3}{|c|}{ Namwawala $(\mathrm{N}=72)$} \\
\hline & $\mathbf{N}$ & Estimate & $P$ value & Estimate & $\mathrm{N}$ & $P$ value \\
\hline \multicolumn{7}{|l|}{ Number Of Rooms } \\
\hline${ }^{\mathrm{a} O}$ One & 37 & 0.76 & 0.0000 & 0.11 & 57 & 0.3485 \\
\hline More than One & 33 & -1.10 & $<0.0001$ & -1.25 & 15 & 0.0081 \\
\hline \multicolumn{7}{|l|}{ Number Of Doors } \\
\hline${ }^{\mathrm{a}}$ One & 30 & 0.86 & 0.0000 & 0.13 & 51 & 0.3207 \\
\hline More than One & 40 & -1.11 & $<0.0001$ & -0.79 & 21 & 0.0167 \\
\hline \multicolumn{7}{|l|}{ Number Of Windows } \\
\hline${ }^{\mathrm{a}}$ Up to 3 & 26 & 0.52 & 0.0003 & 0.07 & 53 & 0.5748 \\
\hline More than 3 & 44 & -0.26 & 0.1997 & -0.55 & 19 & 0.0868 \\
\hline \multicolumn{7}{|l|}{ Netting Over Window } \\
\hline${ }^{\mathrm{a} A b s e n t}$ & 50 & 0.61 & 0.0000 & 0.10 & 60 & 0.3877 \\
\hline Present but damaged & 16 & -1.29 & 0.0003 & -2.76 & 9 & 0.2057 \\
\hline Intact & 4 & -1.40 & 0.0603 & -1.59 & 3 & 0.0251 \\
\hline \multicolumn{7}{|l|}{ House Status } \\
\hline${ }^{\mathrm{a}}$ Small & 12 & 0.85 & 0.0000 & 0.12 & 34 & 0.4408 \\
\hline Large & 58 & -0.60 & 0.0065 & -0.34 & 28 & 0.1534 \\
\hline \multicolumn{7}{|l|}{ Wall Type } \\
\hline${ }^{\text {a Mud }}$ & 52 & 1.25 & 0.0000 & 0.14 & 32 & 0.3365 \\
\hline Cement & 18 & -1.52 & $<0.0001$ & -0.55 & 40 & 0.0439 \\
\hline \multicolumn{7}{|l|}{ Roof Type } \\
\hline${ }^{\mathrm{a}}$ Grass & 46 & 1.17 & 0.0000 & 0.13 & 19 & 0.3283 \\
\hline Metal & 24 & -1.78 & $<0.0001$ & -0.89 & 53 & 0.0131 \\
\hline \multicolumn{7}{|l|}{ Eave Status } \\
\hline${ }^{\mathrm{a}}$ Absent & 46 & -0.73 & 0.0124 & -2.39 & 62 & 0.0222 \\
\hline Present & 24 & 1.42 & $<0.0001$ & 2.48 & 10 & 0.0183 \\
\hline \multicolumn{7}{|l|}{ Eave Size } \\
\hline${ }^{\mathrm{a}}$ Small & 26 & -0.42 & 0.0778 & 0.12 & 22 & 0.4612 \\
\hline Medium & 14 & 1.04 & 0.0001 & -0.36 & 27 & 0.1860 \\
\hline Large & 30 & 1.21 & $<0.0001$ & -0.24 & 23 & 0.4563 \\
\hline \multicolumn{7}{|l|}{ Number of Occupants } \\
\hline${ }^{\mathrm{a}}$ Up to 3 & 15 & 1.05 & 0.0000 & -0.04 & 34 & 0.8015 \\
\hline More than 3 & 55 & -0.96 & $<0.0001$ & -0.00 & 38 & 0.9968 \\
\hline \multicolumn{7}{|l|}{ Bed-net Status } \\
\hline${ }^{\mathrm{a}}$ Untreated & 47 & 0.52 & 0.0000 & 0.85 & 6 & 0.0014 \\
\hline Treated & 23 & -0.52 & 0.0273 & -1.03 & 66 & 0.0005 \\
\hline
\end{tabular}

${ }^{a}$ reference category, $\mathrm{N}=$ number of observations.

Note: Model estimate (ME) value for a factor indicates by how much a factor increases or decreases the indoor mean catches when compared to a reference category.

and number of doors had a significant impact on the mean catches of An. funestus in Namwawala.

\section{Discussion}

Despite high coverage and extensive usage of insecticide treated nets in rural communities of southern
Tanzania [23], partly designed to deter and divert mosquitoes from entering houses [30], a high number of malaria vectors are still found indoors with an average of $22.22(\mathrm{CI}=16.93-27.51)$ An. gambiae s.l. and 1.35 $(\mathrm{CI}=1.07$ - 1.63) An. funestus mosquitoes per trap night per house in Namwawala. In addition, an average 
of $13.12(\mathrm{CI}=10.94-15.30)$ An.gambiae s.l. and 2.09 $(\mathrm{CI}=1.56-2.63)$ An. funestus were collected in Idete per trap night in a house.

Small houses, constituting the majority of houses in the study area, characterized by relatively low numbers of windows, doors and rooms were associated with relatively high densities of malaria vectors. Although the association of house size and indoor mosquito density remains unknown, it was, however, assumed that smaller houses are likely to concentrate more human odours, which would attract high mosquito numbers. Conversely, houses with more sleeping rooms had a lower density of vectors because they usually have more sleeping spaces, which is likely to encourage consistent use of bed nets by sleepers $[31,32]$. Moreover, houses with many rooms are likely to have more nets, which collectively might reduce the number of mosquitoes indoors.

Houses made of mud walls and grass roofs had an increased risk of mosquito bites indoors. Such houses create cooler, darker conditions favoured by resting mosquitoes $[33,34]$. Moreover, mud walls as well as grass roofs often have crevices used by mosquitoes to enter the houses unlike cement walls and metal roofs [18]. In addition, lack of or damaged screening over windows as well as open eaves provided entry points and led to increased mosquito abundance inside the houses. These findings are consistent with other studies [16,35-38] which demonstrated that poorly constructed houses (with mud walls, grass roofs, lack of screening and with eave gaps tend to have increased human-vector exposure), resulting in a higher risk of malaria transmission.

It has been documented that houses with many occupants tend to attract vectors of disease $[39,40]$. In this study, the presence of many sleepers in a small house exposed them to a higher risk of An.gambiae s.l. bites but to a lower risk from An. funestus. Large amounts of human emanations from houses with more occupants tend to increase mosquito attractiveness towards that particular house compared to ones with fewer sleepers $[41,42]$. The observed inverse relationship between $A n$. funestus and number of occupants inside the house was unexpected; however, it might be due to uneven distribution of $A n$. funestus within the villages. Higher numbers of An. funestus collected during the dry season [43] were mostly and consistently from a cluster of a few houses located in a particular village hamlet. Therefore, the majority of houses within the sampling area experienced none or low catches.

Furthermore, significant impacts of house risk factors on An. funestus indoor mean catches were not consistent between villages. While this observation remains inconclusive, we postulated the cause to be exceedingly low numbers of $A n$. funestus collected between villages compared to An. gambiae s.l.
Treated nets provided more protective advantages than untreated ones as also observed in previous studies $[22,23,44,45]$. However, the density of An. gambiae s.l. in Namwawala was higher compared to Idete despite $90 \%$ ITN coverage in Namwawala. These results indicate that even at high coverage levels, ITNs still have limitations in reducing the number of malaria vectors entering the houses. Furthermore, recent studies $[46,47]$ have indicated that poor compliance and usage of bed nets by communities in the tropics is associated with heat discomfort associated with poor airflow caused by bed nets. Although bed nets were procured individually and there was a distribution campaign during the study period, the age of nets as well as usage of ITNs was not systematically investigated in this study, our results illustrate that a risk of transmission remains whenever people are not using treated nets in an optimal way. Improved house designs, and modifications to existing houses could substantially reduce the risk of mosquito-human contact. Although house improvement has been advocated as an efficient intervention for malaria control, the majority of houses in poor rural Africa are temporary and built with minimal material resources. This renders improvements expensive and/or impractical in most rural communities in the short term. Permanent houses (Figure 2b) could be easily and cheaply modified by screening eaves, windows and doors accompanied by community sensitization towards intervention sustainability. Temporary houses (Figure 2a) are less amenable to modifications unless they are rebuilt as more permanent structures. This would have to be addressed through a long-term strategy that sought to build better, inexpensive house models using better construction materials and sustainable financing initiatives, which can be adopted in poor settings. Such an intervention is likely to be beneficial in reducing vector borne diseases and other diseases linked to poor hygiene.

\section{Conclusions}

This study shows the impact of specific housing characteristics on malaria vector density and the associated risk of indoor disease transmission. It also shows that even at high coverage levels of ITNs, there remains a high risk of human-mosquito contact and also that this transmission risk can be mitigated by changing house structure. Communities with permanent, spacious and screened houses are at lower risk of indoor malaria transmission.

\section{Competing interests}

The authors have declared no competing interests.

\section{Authors' contributions}

DWL and SM proposed the study hypothesis. DWL and SSK performed statistical analysis and wrote the first draft of the manuscript. DWL supervised the study data collections. ZDM, CH, SD \& GD contributed to writing of the manuscript. All authors read and approved the final manuscript. 


\section{Acknowledgements}

The study was partly funded by the Bill and Melinda Gates Foundation through the Global Health Program (Seattle, USA), Grant number OPP52644 and the Addessium Foundation (Reeuwijk, The Netherlands). We are grateful to the families in the villages of Namwawala and Idete for their participation in the study. We particularly thank our colleagues who helped in field data collection and processing: Japhet Kihonda, Peter Pazia, Daniel Lugiko, Nuru Nchimbi, Josephat Kihonda, Matrida Kideule, Cecilia Mchope, and Monica Mpingwa. In addition, thanks to Deogratius Roman and Salum Aziz for laboratory sample analysis.

\section{Author details}

1 Biomedical and Environmental Thematic Group, Ifakara Health Institute, P.O. Box 53, Ifakara, Tanzania. Vector Biology Department, Liverpool School of Tropical Medicine, Pembroke Place, Liverpool L3 5QA, UK. ³ Department of Mathematics, Statistics and Computer Science, Marquette University, Milwaukee WI-53201-1881, USA. ${ }^{4}$ Cairns Public Health Unit, Queensland Health, Queensland 4870, Australia.

Received: 17 January 2013 Accepted: 26 February 2013 Published: 7 March 2013

\section{References}

1. Sinka ME, Bangs MJ, Manquin S, Rubio-Palis Y, Chareonviriyaphap T, Coetzee M, Mbogo CM, Hemingway J, Patil AP, Temperley WH: A global map of dominant malaria vectors. Parasit Vectors 2012, 5(1):69.

2. Gillies M, de Meillon B: The Anophelini of Africa south of the Sahara (Ethiopian zoogeographical region). In, South African Institute of Medical Research, Volume 54. Secondth edition; 1968.

3. Pluess B, Tanser FC, Lengeler C, Sharp BL: Indoor residual spraying for preventing malaria. In, Cochrane Report, Volume 4; 2010.

4. WHO: World Malaria Report. Geneva, Switzerland: World Health Organization; 2012.

5. Griffin J, Hollingsworth T, Okell L, Churcher T, White M, Hinsley W, Bousema T, Drakeley C, Ferguson N, Basáñez M: Reducing Plasmodium falciparum Malaria Transmission in Africa: A Model-Based Evaluation of Intervention Strategies. PLoS Med 2010, 7(8):e1000324. doi:10.1371/journal. pmed. 1000324.

6. Kiware SS, Chitnis N, Devine GJ, Moore SJ, Majambere S, Killeen GF: Biologically meaningful coverage indicators for eliminating malaria transmission. Biol Lett 2012, 8(5):874-877.

7. Bayoh MN, Mathias DK, Odiere MR, Mutuku FM, Kamau L, Gimnig JE, Vulule JM, Hawley WA, Hamel MJ, Walker ED: Anopheles gambiae: historical population decline associated with regional distribution of insecticidetreated bed nets in western Nyanza Province, Kenya. Malar J 2010, 9(1):62.

8. Ranson H, Guessan R, Lines J, Moiroux N, Nkuni Z, Corbel V: Pyrethroid resistance in African anopheline mosquitoes: what are the implications for malaria control? Trends Parasitol 2011, 27(2):91-98.

9. Trape J, Tall A, Diagne N, Ndiath O, Ly AB, Faye J, Dieye-Ba F, Roucher C, Bouganali C, Badiane A, Sarr F, Mazenot C, Touré-Baldé A, Raoult D, Druilhe P, Mercereau-Puijalon O, Rogier C, Sokhna C: Malaria morbidity and pyrethroid resistance after the introduction of insecticide -treated bednets and artemisinin-based combination therapies: a longitudinal study. Lancet Infect Dis 2011, 11:925-932.

10. Kitau J, Oxborough RM, Tungu PK, Matowo J, Malima RC, Magesa SM, Bruce J, Mosha FW, Rowland MW: Species Shifts in the Anopheles gambiae Complex: Do LLINs Successfully Control Anopheles arabiensis? PLoS One 2012, 7(3):e31481.

11. Baragatti M, Fournet F, Henry MC, Assi S, Ouedraogo H, Rogier C, Salem G: Social and environmental malaria risk factors in urban areas of Ouagadougou, Burkina Faso. Malar J 2009, 8(1):13

12. Graves PM, Richards FO, Ngondi J, Emerson PM, Shargie EB, Endeshaw T, Ceccato P, Ejigsemahu Y, Mosher AW, Hailemariam A: Individual, household and environmental risk factors for malaria infection in Amhara, Oromia and SNNP regions of Ethiopia. Trans $R$ Soc Trop Med Hyg 2009, 103(12):1211-1220.

13. Schofield CJ, White GB: Engineering against insect borne diseases in the domestic environment. Housing design and domestic vectors of disease. Trans R Soc Trop Med Hyg 1984, 78:285-292.
14. Webb DJ: Low-cost housing and parasite vectors. Parasitol Today (Personal ed) $1985,1(2): 65$.

15. Kumar DVR, Krishna D, Murty US, Sai KSK: Impact of different housing structures on filarial transmission in rural areas of southern India. South East Asian J Trop Med Publ Health 2004, 35(3):587-590.

16. Lindsay SW, Emerson PM, Charlwood JD: Reducing malaria by mosquitoproofing houses. Trends Parasitol 2002, 18:510-514.

17. Lindsay SW, Jawara M, Paine K, Pinder M, Walraven GEL, Emerson PM: Changes in house design reduce exposure to malaria mosquitoes. Trop Med Int Health 2003, 8(6):512-517.

18. Kirby MJ, Green C, Milligan PM, Sismanidis C, Jasseh M, Conway DJ, Lindsay SW: Risk factors for house-entry by malaria vectors in a rural town and satellite villages in The Gambia. Malar J 2008, 7(1):2

19. Kirby MJ, Ameh D, Bottomley C, Green C, Jawara M, Milligan PJ, Snell PC, Conway DJ, Lindsay SW: Effect of two different house screening interventions on exposure to malaria vectors and on anaemia in children in The Gambia: a randomised controlled trial. Lancet 2009, 374:998-1009.

20. Lindsay SW, Snow RW: The trouble with eaves; house entry by vectors of malaria. Trans R Soc Trop Med Hyg 1988, 82:645-646.

21. Ogoma S, Lwetoijera D, Ngonyani H, Furer B, Russell T, Mukabana W, Killeen G, Moore S: Screening Mosquito House Entry Points as a Potential Method for Integrated Control of Endophagic Filariasis, Arbovirus and Malaria Vectors. PLoS Negl Trop Dis 2010, 4(8):e773. doi:10.1371/journal. pntd.0000773.

22. Winskill P, Rowland M, Mtove G, Malima RC, Kirby MJ: Malaria risk factors in north-east Tanzania. Malar J 2012, 10:98. doi:10.1186/1475-2875-10-98.

23. Russell TL, Lwetoijera DW, Maliti D, Chipwaza B, Kihonda J, Charlwood D, Smith TA, Lengeler C, Mwanyangala MA, Nathan R, et al: Impact of promoting longer-lasting insecticide treatment of bed nets upon malaria transmission in a rural Tanzanian setting with pre-existing high coverage of untreated nets. Malar J 2010, 9(187). doi:10.1186/1475-2875-9-187.

24. Killeen G, Tami A, Kihonda J, Okumu F, Kotas M: Cost-sharing strategies combining targeted public subsidies with private-sector delivery achieve high bednet coverage and reduced malaria transmission in Kilombero Valley, southern Tanzania. BMC Infect Dis 2007, 7:121.

25. Russell TL, Lwetoijera DW, Knols BG, Takken W, Killeen GF, Kelly-Hope LA: Geographic coincidence of increased malaria transmission hazard and vulnerability occurring at the periphery of two Tanzanian villages. Malar J 2013, 12(1):24.

26. Schellenberg JRMA, Abdulla S, Nathan R, Mukasa O, Marchant TJ, Kikumbih $\mathrm{N}$, Mushi AK, Mponda H, Minja H, Mshinda H: Effect of large-scale social marketing of insecticide-treated nets on child survival in rural Tanzania. Lancet 2001, 357(9264):1241-1247.

27. Scott JA, Brogdon WG, Collins FH: Identification Of Single Specimens Of The Anopheles-Gambiae Complex By The Polymerase Chain-Reaction. AmJTrop Med Hyg 1993, 49(4):520-529.

28. Koekemoer $L L$, Kamau L, Hunt RH, Coetzee $M$ : A cocktail polymerase chain reaction assay to identify members of the anopheles funestus (diptera: culicidae) group. AmJTrop Med Hyg 2002, 6(6):804-811.

29. Burkot T, Williams J, Schneider I: Identification of Plasmodium falciparum infected mosquitoes by a double antibody enzyme-linked immunosorbent assay. Am J Trop Dis Prevent Med 1984, 33(5):783-788.

30. Okumu FO, Moore SJ: Combining indoor residual spraying and insecticidetreated nets for malaria control in Africa: a review of possible outcomes and an outline of suggestions for the future. Malar J 2011, 10:208.

31. Toe LP, Skovmand O, Dabire KR, Diabate A, Diallo Y, Guiguemd TR, Doannio JM, Akogbeto M, Baldet T, Grunais ME: Decreased motivation in the use of insecticide-treated nets in a malaria endemic area in Burkina Faso. Malar J 2009, 8:175.

32. Iwashita H, Dida G, Futami K, Sonye G, Kaneko S, Horio M, Kawada H, Maekawa Y, Aoki Y, Minakawa N: Sleeping arrangement and house structure affect bed net use in villages along Lake Victoria. Malar J 2010, 9(176). doi:10.1186/1475-2875-9-176.

33. Odiere M, Bayoh MN, Vulule J, Irungu L, Walker E: Sampling outdoor, resting Anopheles gambiae and other mosquitoes (Diptera: Culicidae) in Western Kenya with clay pots. J Med Entomol 2007, 44(1):14-22.

34. Harbison JE, Mathenge EM, Misiani GO, Mukabana WR, Day JF: A simple method for sampling indoor-resting malaria mosquitoes Anopheles gambiae and Anopheles funestus (Diptera: Culicidae) in Africa. J Med Entomol 2006, 43(3):473-479. 
35. Smith A, Hudson JE: A modification to an experimental hut to reduce mosquito eaves-egress. WHO 1972, 72.775(6). http://www.who.int/iris/ handle/10665/65641.

36. Ernst K, Adoka S, Kowuor D, Wilson M, John C: Malaria hotspot areas in a highland Kenya site are consistent in epidemic and non-epidemic years and are associated with ecological factors. Malar J 2006, 5(78). doi:10.1186/1475-2875-5-78.

37. Yé $Y$, Hoshen M, Louis V, Séraphin S, Traoré I, Sauerborn R: Housing conditions and Plasmodium falciparum infection: protective effect of iron-sheet roofed houses. Malar J 2006, 5(8). doi:10.1186/1475-2875-6-46.

38. Sintasath D, Ghebremeskel T, Lynch M, Kleinau E, Bretas G, Shililu J, Brantly $E$, Graves $P$, Beier J: Malaria prevalence and associated risk factors in Eritrea. AmJTrop Med Hyg 2005, 72:682-687.

39. Konradsen F, Amerasinghe P, Van der Hoek W, Amerasinghe F, Perera D, Piyaratne M: Strong association between house characteristics and malaria vectors in Sri Lanka. AmJTrop Med Hyg 2003, 68:177-181.

40. White GB: Factors affecting densities of mosquitoes resting indoors. In Annual Report of the East African Institute of Malaria and Vector-borne Diseases. 1969:37-43.

41. Takken W, Knols B: Odor-mediated behavior of Afrotropical malaria mosquitoes. Annual Rev Entomol 1999, 44:131-157.

42. Port GR, Boreham PFL, Bryan JH: The relationship of host size to feeding by mosquitoes of the Anopheles gambiae Giles complex (Diptera: Culicidae). Bull Entomol Res 1980, 70(01):133-144.

43. Smith T, Charlwood JD, Takken W, Tanner M, Spiegelhalter DJ: Mapping the densities of malaria vectors within a single village* 1 . Acta Trop 1995, 59(1):1-18.

44. Lengeler C: Insecticide-treated bed nets and curtains for preventing malaria. Cochrane Database Syst Rev 2004, 2:CD000363.

45. Killeen GF, Smith TA, Ferguson HM, Mshinda H, Abdulla S, Lengeler C, Kachur SP: Preventing childhood malaria in Africa by protecting adults from mosquitoes with insecticide-treated nets. PLoS Med 2007, 4(7):1246-1258.

46. von Seidlein L, Konstantin I, Bruun R, Jawara M, Pinder M, Knols BG, Knudsen JB: Airflow attenuation and bed net utilization: observations from Africa and Asia. Malar J 2012, 11(1):200.

47. Pulford J, Hetzel MW, Bryant M, Siba PM I: M: Reported reasons for not using a mosquito net when one is available: a review of the published literature. Malar J 2011, 10(83). doi:10.1186/1475-2875-10-83.

doi:10.1186/1756-3305-6-57

Cite this article as: Lwetoijera et al:: A need for better housing to further reduce indoor malaria transmission in areas with high bed net coverage. Parasites \& Vectors 2013 6:57.

\section{Submit your next manuscript to BioMed Central and take full advantage of:}

- Convenient online submission

- Thorough peer review

- No space constraints or color figure charges

- Immediate publication on acceptance

- Inclusion in PubMed, CAS, Scopus and Google Scholar

- Research which is freely available for redistribution 